Dig Dis 1994;12:I-IV

\title{
Contents Vol. 12,1994
}

\section{No. 1}

Publisher's Note 1

Diamine Oxidase: An Overview of Historical, 2

Biochemical and Functional Aspects Wolvekamp, M.C.J.; de Bruin, R.W.F.

Mechanisms of Small Intestinal Adaptation 15

Jenkins, A.P.; Thompson, R.P.H.

Nitric Oxide: An Ubiquitous Actor in the 28

Gastrointestinal Tract Guslandi, M.

Cytoprotection with Misoprostol: Use in the 37

Treatment and Prevention of Ulcers Ballinger, A.

Chronic Refractory Diarrhoea: A Manifestation 46 of Endocrine Disorders Alam, M.J.

Treatment of External Biliary, Pancreatic and

62

Intestinal Fistulas with a Somatostatin Analog Kocak, S.; Bumin, C; Karayalcin, K.; Alacayk, I.; Aribal, D.

Announcement 68

No. 2

The Irritable Bowel Syndrome: Motility, Mind or 69 Message? Variations on an Enigma

Quigley, E.M.M.

Intestinal Motor Function in Irritable Bowel 72

Syndrome

Gorard, D.A.; Farthing, M.J.G.

Calcium Supplementation as Prophylaxis against 85 Colon Cancer?

Kleibeuker, J.H.; Cats, A.; van der Meer, R.; Lapré, J.A.; de Vries, E.GE

Barrett's Oesophagus 98

Thomsen Bernstein, I.; Kruse, P.; Bak Andersen, I.

Hirschsprung’s Disease and Mimicking 106

Conditions

Doig, CM.

Surgery for Gastric Cancer 117

Wyman, A.; Karatsis, P.; Rogers, K.

No. 3

Editorial

Passing of the Torch Achem, S.R.

127

A Diagnostic Approach to Pancreatic Cancer Foutch, P.G.

129 
Alpha-1 -Antitrypsin Deficiency and Liver 139

Disease

Propst, T.; Propst, A.; Dietze, O.; Judmaier, G;

Braunsteiner, H.; Vogel, W.

Hydatid Liver Disease: A Perspective in $\quad 150$

Treatment

Mente§, A.

Metal Stents for Malignant Biliary Obstruction 161 Laméris, J.S.; Stoker, J.

Aspirin and Neoplasia of the Digestive Tract: $\quad 170$

Is There a Chemopreventive Effect? Lancaster, T.; Silagy, C.

Vegetarianism, Dietary Fibre and Gastro-Intesti- 177

nal Disease

Nair, P.; Mayberry, J.F.

Infertility, Obstetric and Gynaecological Prob- 186 lems in Coeliac Sprue

Sher, K.S.; Jayanthi, V.; Probert, C.S.J.; Stewart, C.R.; Mayberry, J.F.

111

No. 4

Hepatobiliary Complications in Adults Receiving 191 Nutrition Support Fleming, C.R.

Intestinal Manometry in Man: A Historical and 199 Clinical Perspective Quigley, E.M.M.

NSAID-Induced Peptic Ulcer Disease: A Critical 210 Review of Pathogenesis and Management Scheiman, J.M.

Osteoporosis in Chronic Liver Disease: 223

Pathogenesis, Risk Factors, and Management McCaughan, G.W.; Feller, R.B.

Leukocyte-Endothelial Cell Interactions: Implica- 232 tions for the Pathogenesis and Treatment of Gastrointestinal Disease Panes, J.; Granger, D.N.

Gallstones and Acute Pancreatitis - Mechanisms 242

and Mechanics

Lerch, M.M.; Hernandez, C.A.; Adler, G.

Is Vitamin E Depleted in Crohn's Disease at 248

Initial Diagnosis?

Kuroki, F.; Iida, M.; Tominaga, M.; Matsumoto, T.; Kanamoto, K.; Fujishima, M.

Sulindac Therapy of Colorectal Polyps in Famil- 259 ial Adenomatous Polyposis Tonelli, F.;

Valanzano, R.; Dolara, P.

Hepatitis Delta Virus Infection: Molecular 265

Biology and Treatment

Carreño, V.; Bartolome, J.; Madejón, A.

Alcohol and the Risk of Cancers of the Stomach 276 and Colon-Rectum Franceschi, S.; La

Vecchia, C.

Cytokines (Immunoinflammatory Hormones) 290 and Their Natural Regulation in Inflammatory

Bowel Disease (Crohn's Disease and Ulcerative Colitis): A Review

Brynskov, J.; Haagen Nielsen, O.; Ahnfelt-Rønne, I.; Bendtzen, K.

The Role of Blood Flow in Gastric Mucosal 305

Defence, Damage and Healing Sørbye, H.; Svanes, K.

Colitis cystica profunda: Self-inflicted by Rectal 318

Trauma? Report of a Case

Lifshitz, D.; Cytron, S.; Yossiphov, J.; Lelcuk, S.; 
Rabau, M.

No. 6

Pathology of AIDS-Related Liver Disease 321

Lefkowitch, J.H.

Primary Biliary Cirrhosis 331

Laurin, J.M.; Lindor, K.D.

Bioavailability of Alcohol: Role of Gastric 351

Metabolism and Its Interaction with Other Drugs Baraona, E.; Gentry, R.T.; Lieber, C.S.

Placebo and Placebo Effect: Their Impact on the 368 Evaluation of Drug Response in Patients Dobrilla, G; Scarpignato, C.

Acknowledgement to the Reviewers 378

Author Index Vol. 12380

Subject Index Vol. 12381

IV

Contents 